Revista de la red interuniversitaria de estudios sobre las literaturas rioplatenses contemporáneas en Francia

$10 \mid 2014$

El XIX en el XX

\title{
Fragmento de El sueño del señor juez (2008)
}

\section{Carlos Gamerro}

\section{OpenEdition}

Journals

\section{Edición electrónica}

URL: http://journals.openedition.org/lirico/1660

DOI: $10.4000 /$ lirico.1660

ISSN: 2262-8339

Editor

Réseau interuniversitaire d'étude des littératures contemporaines du Río de la Plata

Referencia electrónica

Carlos Gamerro, «Fragmento de El sueño del señor juez (2008) », Cuadernos LIRICO [En línea], $10 \mid 2014$ Puesto en línea el 15 marzo 2014, consultado el 19 abril 2019. URL : http://journals.openedition.org/ lirico/1660 ; DOI : 10.4000/lirico.1660

Este documento fue generado automáticamente el 19 abril 2019.

\section{(c) (i) (9)}

Cuadernos LIRICO está distribuido bajo una Licencia Creative Commons Atribución-NoComercialSinDerivar 4.0 Internacional. 


\title{
Fragmento de El sueño del señor juez (2008)
}

\author{
Carlos Gamerro
}

\section{NOTA DEL AUTOR}

[El texto es parte de un libro sobre la literatura argentina y el imaginario nacional que será publicado por Penguin Random House en el 2015]

1 El juez mismo empezaba a intranquilizarse, sintiéndose poco a poco perder el control sobre sus propios sueños, que se volvían cada vez más intrincados y bizarros, desafiando la interpretación o el desmadejamiento, cayendo sus remedios cada vez más fuera de la letra de la ley, obligándolo a lecturas minuciosas del Código Rural que lo dejaban más perplejo que antes, alelado, como si una bruma que nunca terminara de disiparse del todo flotara permanentemente sobre su cabeza, velando la vista clara y nítida del mundo exterior. "Es como un halo de humo pardo" la describía mamá Culebrilla, la curandera, que aseguraba verla cuando el juez pasaba ensimismado en su caballo. "Nunca duerme" o "nunca despierta" cuchicheaban las mujeres a su paso ; era como si se hubiera disuelto la barrera entre ambos mundos y el juez encontrara, al abrir los ojos, los mismos objetos y los mismos personajes que habían atormentado sus pesadillas. Rancho por rancho hizo dar vuelta como un guante en caserío y estancia cuando despertó bañado en lágrimas, tras soñar que su mamita muerta estaba en el pueblo y lo llamaba. La noche siguiente soñó que en su ausencia unos chicos malos lo empujaban a la zanja y se reían de él a carcajadas mientras se ahogaba : empapado saltó de la cama e hizo comparecer a todos los padres con sus hijos menores de edad, a los cuales hizo encerrar en el calabozo sin agua ni comida hasta que sus progenitores de ambos sexos (como hizo figurar en actas) rellenaran con tierra el sector del viejo foso de defensa donde había ocurrido la tragedia.

2 Le pasaba a menudo, de sentir que empezaba a ahogarlo la vida feral del desierto, el aire cargado de polvo y sangre que nunca terminaban de asentarse. Se dejaba crecer la barba, 
se olvidaba de bañarse, se perdía de comer por el hastío de la invariable dieta de maíz y galleta y carnes duras. Y el alerta permanente de los malones, que se diría le corrían por las entrañas, tanto turbaban su sueño. A veces subía al mangrullo, solo, y se quedaba horas mirando hacia el noreste, como si a fuerza de empecinarse sus ojos pudieran tironear hasta el horizonte la ciudad de Rosario, donde su mujer y sus hijos disfrutaban de la vida regalada que a costa de enormes sacrificios él arrancaba de estas tierras bárbaras, que ahora ni siquiera respetaban el sagrario de sus sueños. Desde esa altura sería además el primero en ver la nube de polvo anunciando la llegada de la mensajería, ya dos días demorada, en la cual para que la ilusión lo sostuviera decidió inmotivadamente que llegaría por fin el agrimensor. Había estado toda la semana soñando con él, y en el sueño le daba indicaciones precisas de cómo quería los bulevares, las plazas, las fuentes ; todo el trazado, en fin, del pueblo que tendría su estatua por centro; y cuando al crepúsculo finalmente entró la diligencia, rengueando sobre los rayos astillados y mal compuestos de una de las ruedas traseras, y descargó su contenido mediocre y rotoso de mercachifles y gringos perdidos, sin decir una palabra y dejando a cargo del sargento el registro de los recién venidos, el juez se dirigió cabizbajo a su vivienda para descargar su rabia y su tristeza en el vientre sin fondo de la Ceferina, indiferente e ilimitado como el desierto mismo. Tras leer apenas se durmió con el libro de Eugenio Sue entre las manos ; la mujer, una vez que por su respiración pesada estuvo segura, alterando apenas la ondulación de las sábanas se deslizó fuera como una anguila y, tras ponerse la enagua y apagar el candil, se acostó sobre el poncho a los pies de la cama.

3 En su sueño, el juez por fin conocía París. Visitaba el Louvre, las Tullerías, iba a la Opera de cuya inauguración reciente se había interiorizado por los periódicos, y por la noche consumía botellas de champán en los elegantes restaurantes, frecuentaba cabarets y lenocinios. Pero todo era sutilmente distinto a lo que siempre había soñado. En el Bois de Boulogne, por ejemplo, descubrió en un claro del altivo y frondoso follaje de robles y encinas la silueta retacona y casi obscena de un ombú. La berlina que lo llevaba a la Ópera empezó a traquetear molestamente y al asomarse por la ventana sin vidrios distinguió a los petisitos criollos de crin dura tironeando empecinados, y los dedos del postillón, negros y de uñas costrosas, asomando de las botas de potro. "No, no, llévenme a la Ópera", gritó el juez en un principio de pánico, que recibió en respuesta apenas la sonrisa amarilla del mulato. De poncho y chiripá entre los elegantes caballeros de frac y las damas drapeadas de seda se sentía peor que desnudo, pero nadie parecía darse cuenta, o por buena educación fingían no hacerlo; ni siquiera fruncían la nariz cuando se insinuaba entre sus exquisitas fragancias y perfumes una tuforada de grasa de yegua. Se sintió tan aliviado de alcanzar su palco antes de que lo descubrieran y lo echaran a la calle, que no le importó que en lugar de sillones de brocado y damasco hubiera taburetes de paleta y cuero, ni siquiera que detrás de él comenzara a desfilar un tren interminable de indios bolivianos que sentándose en el suelo se pusieron a mascar coca y escupir sobre la baranda hacia las plateas. Uno de ellos le preguntó el nombre de la ópera y lanzó un verde escupitajo de desprecio cuando el señor juez no supo decirle si Aída o Tristán e Isolda. Se levantó el telón y en medio del imponente escenario apareció paradito un chino con un charanguito de mulita que sin preámbulos empezó a rasgar frenéticamente, marcando el compás con pataditas en el suelo. El público estalló en un delirio, los caballeros arrojando sus galeras al aire, las damas desmayándose de emoción en sus butacas o corriendo hasta el borde del foso para arrojar orquídeas, joyas y prendas íntimas a los pies del enano saltarín que entusiasmado alzaba un brazo y gritaba jAhora todos! mientras el juez trataba de explicarle a las damas y caballeros asomados medio cuerpo afuera de los palcos 
vecinos "no, por favor, así no es, los están engañando, ¿no se dan cuenta?" y en el restaurante cuando trató de reclamarle al sommelier que le habían servido chicha en lugar de champagne éste resopló ofendido y se fue a cuchichear con el maitre, que sacudía la cabeza contrito cada vez que lo señalaba, por lo cual ni se atrevió a protestar cuando en lugar de las ostras gratinadas que había pedido el garçon descubrió bajo la campana de plata una humeante parva de huesos con caracú. En el bulevar le pidió al mulato que lo llevara al mejor cabaret, pero ya había perdido toda esperanza, y cuando en el can-can de Offenbach salió a escena una doble fila de cholas gordas con dientes de oro, sacudiendo las trenzas bajo los bombines y levantando a destiempo las múltiples faldas raídas para mostrar que no llevaban nada debajo - fatigada alguna cada tanto se agachaba en el piso abombándolas para hacer pis - el señor juez ocultó la cabeza entre las manos y prorrum pió en sollozos de niño estafado. ¿Esto era? ¿Para esto esperé toda mi vida? 